\title{
European Union Intellectual Property Standards in the Framework of the ongoing Negotiations of a Free Trade Agreement between the EU and India
}

\author{
Marta ORTEGA GÓMEZ*
}

\begin{abstract}
The negotiations of a free trade agreement (FTA) between India and the European Union started in mid-2007 and have yet to be concluded. Negotiations surrounding the intellectual property rights chapter have been a major stumbling block given that the parties have differing agendas in this area. This article examines the negotiating parties' positions on sensitive issues such as availability of patents, patent exceptions, data exclusivity and technology. Another major question refers to both parties positions towards the so name TRIPS-plus agreements, as the Anti-counterfeiting Free Trade Agreement. Whilst the EU is a firm promoter of this type of agreement, India is openly against it. Despite the different views on intellectual property rights, the EU is close to accepting Indian positions.
\end{abstract}

Keywords: Patents - EU - India - TRIPS - TRIPS-plus - Technology Transfer.

\section{THE WAY TOWARDS A FREE TRADE AGREEMENT BETWEEN THE EUROPEAN UNION AND INDIA}

The European Union (hereinafter the EU) and India opened negotiations ${ }^{\mathrm{I}}$ on a free trade agreement (FTA) in June 2007. ${ }^{2}$ Between mid-2007 and mid-2014 there were fourteen rounds of negotiations between Brussels and New Delhi. Despite the long-running negotiations, it is uncertain whether this

* Associate Professor of Public International Law -European Union Law, University of Barcelona, martaortega@ub.edu.

I On this topic, see: C. Correa, Negotiation of a Free Trade Agreement European Union-India: Will India Accept TRIPS-plus Provisions? (University of Buenos Aires, Oxfam, 2009, at http://www.oxfam.de/files/20090609_negotiationofafreetradeaggrementeuindia_2I8kb.pdf); M. Ortega Gómez, Patentes Farmacéuticas y Países en Desarrollo (Difusión Jurídica, Madrid, 20II) at I82-188, 207-2II; Corporate Europe Observatory/India FDI Watch, Trade Invaders. How Big Business Is Driving the EU-India Free Trade Agreement (Corporate Europe Observatory, Brussels-Delhi, 2010, available electronically at http://corporateeurope.org/sites/default/files/publications/trade_invaders_o.pdf); J. Wouters et al., 'Some critical Issues in the India Free Trade Agreement Negotiations', Leuven Centre for Global Governance Studies, Working Paper No IO2, February 2013, at http://papers.ssrn.com/sol3/papers.cfm?abstract_id=2249788.

2 The United States has concluded free trade agreements (FTAs) with twenty countries. These are more comprehensive and stricter than World Trade Organization agreements. The EU has followed this same legal technique in order to strengthen its relations with privileged allies although it has a small number of agreements in effect. The EC signed a full Economic Partnership Agreement with Cariforum in 2008 (OJEU L 289, 30.10.2008, p. I). The EU has also successfully concluded free trade agreements with South Korea (20II, Council Decision of 16 September 2010 on the signing, on behalf of the European Union, and provisional application of the Free Trade Agreement between the European Union and its Member States, of the one part, and the Republic of Korea, of the other part (201I/265/EU, OJEU L I27 I4.5.20II)) and with Singapore (2013, not in force at the time of writing this article).

The EU is currently negotiating free trade agreements with the USA: the Transatlantic Trade and Investment Partnership (TTIP). These talks started with a round held on 8-I2 July 2013 in Washington, D.C. With regard to the TTIP negotiations see: European Parliament, 'Overcoming Transatlantic differences on intellectual property. IPR and the TTIP negotiations', Carmen-Cristina Tirlig- European Parliament Research Service, 20I4, at <http://www.europarl.europa.eu/RegData/bibliotheque/briefing/20I4/I40760/LDM_BRI\%2820I4\%29I40760_REVI_EN.pd $\mathrm{f}>$, with Canada (negotiations started in October 2013) and with Japan (negotiations started in April 2013). The EU is also negotiating this type of agreement with non-developed countries: Morocco, Vietnam, Thailand and Malaysia. The Commission also has a mandate to start a similar process with Tunisia, Egypt and Jordan. 
agreement will be concluded as important differences still remain between the two parties. ${ }^{3}$ At the same time, there is an economic incentive for this European and Indian investment and trade agreement on both economic and strategic grounds ${ }^{4}$, given that the $\mathrm{EU}$ is India's largest trading partner and India is a very important destination for EU exports. 5

The two parties have been negotiating a comprehensive and rather ambitious agreement, a mixed agreement that covers the following areas: trade, investment, services, insurance, government IIIprocurement, labour rights, sustainable development and intellectual property rights. The negotiation of the chapter on intellectual property rights has been a contentious one, but despite the difficulties, the two negotiating parties have made important progress. As a matter of fact, the European Commission, in charge of the negotiations on behalf of the $\mathrm{EU}^{6}$, proposed in July 2013 to include a provision stressing that the EU does not require India to change its intellectual property rights legislation in relation to access to medicines. ${ }^{7}$ The European Commission proposal demonstrates that the EU is close to accepting Indian Patent Law as it stands. ${ }^{8}$ On the side of the EU, acceptance of the FTA will ultimately depend on the Council, which must approve it unanimously (art. 207.4 TFEU).?

This position means that the European Commission has finally yielded ground to India as both parties have traditionally maintained different bargaining positions in the field of intellectual property rights.

The present article is dedicated to an examination of the intellectual property issues under negotiation that are sensitive for both parties. It has been built up on the basis of the views that India

Over automobiles, food safety, spirits, services and public procurement.

4 European Parliament, Directorate-General for External Policies. Policy Department: Workshop. The Long Road

Towards an EU-India Free Trade Agreement, INTA, 20I3, p. 8, http://www.europarl.europa.eu/document/activities/cont/201310/20131023ATT73262/20131023ATT73262EN.pdf.

5 European Parliament, supra n. 4.

6 According to art. 207.3 TFEU. Art. 207.3 TFEU lays down that "the Commission shall conduct these negotiations in consultation with a special committee appointed by the Council to assist the Commission in this task and within the framework of such directives as the Council may issue to it. The Commission shall report regularly to the special committee and to the European Parliament on the progress of negotiations".

7 Parliamentary questions, 16 July 20I3, Answer given by Mr De Gucht on behalf of the Commission, OJ C $47 \mathrm{E}$, I9/02/20I4.

8 On this point, see below.

9 The European Commission negotiates the agreement and the Council authorizes its conclusion in conformity with art. 207 TFEU. The Commission is not free to conduct the negotiations. In the first place, the Commission must obtain the Council's authorization or mandate to start the negotiations. The Commission makes a mandate proposal to the Council, which usually amends it or even rejects it. "This mandate contains 'negotiating directives', which guide the Commission's engagement with the relevant negotiating partner(s); the mandate also specifies who will be conducting the negotiations, typically the Commission, and the Council committee which must be consulted by the Commission during negotiations. In trade and investment policy, the relevant committee is the Trade Policy Committee. Throughout negotiations, the Commission reports back to this Committee and, on technical issues, to its various working groups. Normal practice involves the Commission consulting the relevant working groups before each negotiating round and debriefing them afterwards. (....) At the end of any negotiations, the Council must also adopt a decision to sign and conclude an agreement. When an agreement is mixed, it must also be ratified in Member States, typically by their national parliaments." HM Government, 'Review of the Balance of Competences between the United Kingdom and the European Union Trade and Investment'. February 20I4, at 29-30, document available electronically at <https://www.gov.uk/government/uploads/system/uploads/attachment_data/file/279322/bis_I4_59I_balance_of_competence s_review_Trade_and_investment_government_response_to_the_call_for_evidence.pdf $\rangle$. 
and the European Union have maintained before the World Trade Organization (WTO) as well as their respective internal laws. Accordingly, the paper considers the following issues: the negotiating parties' view of the utility of intellectual property rights, their respective positions on the enforcement of intellectual property rights (including their views on TRIPS-plus compromises), and the question of harmonizing their internal intellectual property laws. The fact that the EU, in 2013, withdrew the requirement that India change its internal law on patents, as well as the fact that Indian domestic law on patents has remained unchanged since the enactment of the Patent (Amendment) Act in 2005 (which implements the Agreement on Trade Related Aspects of Intellectual Property Rights $(\text { TRIPS })^{\mathrm{ro}}$ agreement into Indian Law), provides the information necessary to identify the main lines of the negotiation with regard to intellectual property. Actually, the two facts mentioned above are proof that India is not willing to make any international commitment that would entail new obligations in the field of intellectual property to render Indian intellectual property law more protective $^{\text {II }}$. After an examination of the sensitive issues under negotiation in the field of intellectual property, the present paper analyses the consequences for the pharmaceutical industry arising from a free trade agreement adapted to Indian law.

\section{FUNCTION AND UTILITY OF INTERNATIONAL INTELLECTUAL PROPERTY LAW}

India and the EU have different views as to the function, aims and utility of intellectual property laws. As a matter of fact, India has an undeveloped country's perspective on intellectual property law. Developed countries seek to expand international protection of intellectual property while developing countries seek to weaken the existing obligations. ${ }^{12}$

Both India and the EU had expressed their differences over the role of intellectual property rights during the negotiation that preceded the signing of the TRIPS agreement. Indeed, India had voiced serious reservations about the relevance and utility of TRIPS during its negotiations. ${ }^{13}$ In its Communication of 5 September 1989 to the Negotiating Group on Trade Related Aspects of

Io Marrakech, 1994, in force since I January 1995. With regard to the objectives of the TRIPS agreement, see Peter K You, 'The Objectives and Principles of the TRIPS Agreement' 46 Houston Law Review (2009) 980-Ior6. D. Gervais studies the objectives of the agreement in his book The TRIPS Agreement: Drafting History and Analysis, 3rd ed., (Sweet and Maxwell, London, 2008), at I55. On the TRIPS agreement, see also F.Abbot, F.Cottier, F. Gurry, International Intellectual Property in an Integrated World Economy, Wolters Kluwer, Nueva York, 2007; C.M. Correa, Trade Related Aspects of Intellectual Property Rights. A Commentary on the TRIPS Agreement (Oxford University Press, Nueva York, 2007); C.M. Correa, A. Yusuf, (eds.): Intellectual Property and International Trade. The Trips Agreement, (2a ed., Wolkers Kluwer, London, 2005; M. López Escudero,: 'Capítulo VII - Los derechos de propiedad intelectual en el comercio internacional', L.M. Hinojosa, J. Roldán, (DirS.): Derecho internacional económico (Marcial Pons, Madrid - Barcelona - Buenos Aires, 20Io), at I63; D. Matthews, Globalizing Intellectual Property Rights. The TRIPS Agreement (Routledge, London, 2002); UNCTADICTSD: Resource Book on TRIPS and Development (Cambridge University Press, Cambridge, 2005). B.M. Pires de Carragim, B.M.Pyres de Karragyme: The TRIPS Regime of Patent Rights, ( $2^{\mathrm{a}}$ ed., Kluwer Law International, London, Leiden, 1997). Collective issue, 'Una década del Acuerdo ADPIC. Avances en la protección de la innovación' 42 Comunicaciones en Propiedad Industrial y Derecho de la Competencia, CEFI (2006); P.T.Stoll, J.Busche, K. Arend, WTO Trade-Related Aspectos of Intellectual Property Rights (Max Planck Commentaries on World Trade Law- Martinus Nijhoff, Leiden, 2009).

II See below.

I2 J.H. Reichman, 'Universal Minimum Standards of Intellectual Property Protection under the TRIPS Component of the WTO Agreement', 29 INT'L LAW (1995) 345, 35 I.

r3 P.K. Yu, 'The Objectives...' , supra, n. Io, at 9. 
Intellectual Property Rights, including Trade in Counterfeit Goods, India invoked its freedom to determine the scope and level of protection of intellectual property according to its own interests. India underpinned its view by submitting that historically countries have raised the level of protection granted to intellectual property rights as they attained higher levels of technological and economic development. In this statement, India highlights the primacy of public interests, non-reciprocity and independence of intellectual property rights protection. ${ }^{14}$

Also in the context of the TRIPS negotiations, the views of the European Community (EC) contrasted significantly with the abovementioned proposals advanced by India. The EC proposed common substantive standards in the field of intellectual property rights as well as principles for the reduction of trade distortions and impediments. ${ }^{15}$

Ultimately, the TRIPS agreement reconciled the two views of the role of international rules on intellectual property. To a large extent, it respects the autonomy of the parties with regard to intellectual property rights, but it also establishes minimum common substantive standards, particularly with regard to the scope of intellectual property rights and to enforcement. It is clear that India has not changed its view on the utility of international intellectual property law since the conclusion of the TRIPS agreement. ${ }^{16}$ And it is also very clear that at the time of writing this paper it has no intention of going beyond the TRIPS commitments.

According to the latter, however, it does appear that India might be ready to accept a future FTA aimed at the fulfilment of the objectives in art. 7 of TRIPS, which it already accepted in 1994, at the signing of the TRIPS agreement. Article 7 of the TRIPS agreement sets out the following objectives: the protection and enforcement of intellectual property rights, the promotion of technological innovation and the transfer and dissemination of technology to the mutual advantage of producers and users of technological knowledge in a manner conducive to welfare, and to a balance of rights and obligations. Technology transfer, technological development, social and economic welfare and free trade represent fundamental issues for India. In effect, these aims are essential priorities which, in the Indian view, take precedence over the protection of intellectual property rights.

On the other hand, the objectives set out in the EU-South Korea FTA provide evidence of the EU's intentions in the area. This bilateral agreement aims "'to facilitate production and trade of innovative products and to attain an adequate level of protection and effective compliance of intellectual property rights (art.IO.I)" ${ }^{17}$ The EU-Singapore FTA concluded on 17 October 2014 (but

${ }_{14}$ 'Applicability of the basic principles of the GATT and of the relevant international intellectual property agreements or conventions: Communication from India', Document MTN/GNG/NGII/W/39 dated 5 September 1989 , at 6.

is TRIPS Negotiating Group, 'Guidelines and Objectives Proposed by the European Community for the Negotiations on Trade Related Aspects of Substantive Standards of Intellectual Property Rights' MTN.GNG/NGir/W/26 (July 7, I988). During the TRIPS negotiations, the United States went further than the European Communities in the sense that they claimed common standards on intellectual property rights but not just that: they considered that border measures to impede infringements were also necessary. USTRIPS Negotiating Group, 'Guidelines Proposed by the European Community for the Negotiations on Trade-Related Aspects of Intellectual Property Rights', MTN.GNG/NGir/W/16 (Nov. 20, 1987).

${ }_{16}$ India refused to intervene in the negotiations leading to the Anti-Counterfeiting Trade Agreement. On the other hand, its internal laws and practices with regard to intellectual property rights show a lower degree of protection compared to the protection guaranteed in the Member States of the EU.

${ }^{17}$ OJEU L I24, I4.5.20II, at 43. The EU-South Korea FTA entered into force on I July 20II. See: European Commission: 'The EU-Korea Free Trade Agreement in practice', 20Ir:I5-16, 
not yet in force) puts forward the same objectives in the field of intellectual property (article II.I of the FTA). ${ }^{18}$ The EU-South Korea agreement entered into force in 20II. As can be observed in both treaties, the EU's interests consist of an adequate level of intellectual property protection and effective compliance with intellectual property rights. The EU seeks to go beyond the TRIPS agreement. This position is far from the Indian thesis on the required level of protection for intellectual property rights.

\section{THE PARTIES' POSITIONS WITH REGARD TO TRIPS-PLUS AGREEMENTS}

The TRIPS agreement lays down basic (albeit important) ${ }^{19}$ principles and norms in the field of intellectual property, leaving wide discretion to Member States with regard to sensitive issues in the field of intellectual property, like the scope of exceptions to intellectual property rights, concrete sanctions aimed at the effective enforcement of intellectual property rights (for instance, border measures) and the question of data protection. Thus, the TRIPS agreement harmonizes certain basic substantive principles (like the length of the intellectual property rights covered under the agreement), but detailed and specific measures depend on the internal law of Members to the TRIPS agreement.

As has been pointed out, it appears to be clear that the commitments of State parties attained under the TRIPS agreement in the field of intellectual property are enough for India. In particular, the fact that India did not choose to take part in the negotiation that led to the adoption of the AntiCounterfeiting Free Trade Agreement (ACTA) shows that India has no intention of accepting TRIPS-plus commitments, which consist of international obligations in the field of intellectual property that go beyond the TRIPS commitments on enforcement in order to guarantee effective compliance with and full respect of intellectual property rights. The ACTA requires State parties to impose severe sanctions ${ }^{20}$ on persons who are responsible for infringements of trademarks and

(http://trade.ec.europa.eu/doclib/docs/20II/october/tradoc_I48303.pdf). See also: William H. Cooper et al., 'The EU-South Korea Free Trade Agreement and Its Implications for the United States', Cornell University ILR School (2010), at http://digitalcommons.ilr.cornell.edu/cgi/viewcontent.cgi?article=I80o\&context=key_workplace) and Der-Chin Horng, 'Reshaping the EU's Policy in a Globalizing Economy: the Case of the EU-Korea FTA' 46 Journal of World Trade Law no. 2 (20I2) at 30I-326. Semertzi addresses the question of the direct effect of this type of agreements in "The preclusion of direct effect in the recently concluded EU free trade agreements" Common Market Law Review (2014) at II25-II58.

18 On 30 October 2014, the European Commission stated that it intends to ask the Court of Justice of the EU for an opinion concerning the EU-Singapore free trade agreement as some specific questions concerning EU competences still remain unanswered. European Commission Press Release: http://europa.eu/rapid/press-release_IP-I4-I235_en.htm.

19 One of the most important provisions of the TRIPS agreement on patents is the one that establishes that patent protection lasts for twenty years in all Member States to the agreement. Another one requires that patents may only be granted if three requirements are met: the invention must be new, innovative and susceptible of industrial application. The TRIPS agreement does not specify the contents of the mentioned concepts, leaving it up to the States signing the agreement to lay down precise rules on patentability. On the other hand, the exceptions to patentability are included in an open clause. With regard to the exceptions to patentability in the TRIPS agreement, see: M. Martínez Barrabés, La patente biotecnologica $y$ la OMC (Marcial Pons, Madrid-Barcelona-Buenos Aires, 2013).

${ }_{20}$ In this sense, for instance, art. 17.2 of the ACTA provides for the seizure of illegal goods at the border and art. 20 of the ACTA provides for the destruction of illegal goods. In addition, art. 9.2 of the ACTA lays down that the infringer shall pay the right holder the infringer's profits attributable to the infringement. Further on, art. 23 of the ACTA states that criminal sanctions will be imposed "at least in cases of wilful trademark counterfeiting or copyright or related rights piracy on a commercial scale". 
copyright as well as infringements of patent rights. One of its targets is to combat imports of medicines that infringe on intellectual property rights protected in the territory of the State parties.

In this regard, India's accession to an agreement based on the philosophy of the ACTA, seen as a developed countries' agreement, is unthinkable (the ACTA is in fact a failed agreement as it is not in force $^{21}$. In effect, India opposed and declined to join the ACTA negotiations from the outset. Hence, the notion must be discarded that India might accept any future commitment in the short or middle term that would be stricter than the intellectual property regime established under the TRIPS agreement.

A variety of reasons have led the EU not to ratify the ACTA after the European Parliament declined to give its consent in the summer of 2012. ${ }^{22}$ Regardless of the parliamentary blockage, the Council of the EU (giving support to Japan and the United States) has supported and promoted the ACTA as a tool to prevent international trade in goods that infringe on intellectual property rights. For this reason, it seems unlikely that the EU will accept an express exclusion from adherence to TRIPS-plus agreements in any future FTA between India and the EU. Indeed, effective enforcement of intellectual property rights and the imposition of effective sanctions in the case of infringement are key elements in the EU strategy on intellectual property. ${ }^{23}$

As indicated, India and the EU have different positions on the enforcement of intellectual property laws. Without a doubt, the rules laid down in Chapter III of the TRIPS agreement on

${ }_{21}$ According to art. 6.2 of the agreement, "this agreement shall enter into force 30 days after the deposit of the sixth instrument of ratification, acceptance, or approval as between those signatories which have deposited their respective instruments of ratification, acceptance or approval." On 4 October 20I2, Japan became the first to ratify the treaty. Switzerland and Mexico have withdrawn from the treaty. One of the most controversial issues resulting from the ACTA is the question of the seizure of so-called "counterfeited generic medicines" at the borders of State parties as it is not clear whether this would entail the seizure of medicines which are legally produced in India in transit at the EU border and destined to non-developed countries. B. Mercurio, 'Seizing' Pharmaceuticals in Transit: Analysing the WTO Dispute that Wasn't", 6I International Comparative Law Quarterly (2012), at 389-426.

${ }_{22}$ The European Parliament's legislative resolution of 4 July 2012 on the draft Council decision on the conclusion of the Anti-Counterfeiting Trade Agreement between the European Union and its Member States, Australia, Canada, Japan, the Republic of Korea, the United Mexican States, the Kingdom of Morocco, New Zealand, the Republic of Singapore, the Swiss Confederation and the United States of America (12195/2011 - C7-0027/2012 - 2011/0167(NLE)). The European Parliament's refusal follows a series of resolutions which had been adopted in 2010 that criticize the lack of transparency in the process that led to the adoption of the ACTA: 'The Anti-Counterfeiting Trade Agreement', European Parliament resolution of 24 November 2010 on the Anti-Counterfeiting Trade Agreement (ACTA) 24-II-2010, P7_TA (2010)0432; 'The lack of a transparent process for the Anti-Counterfeiting Trade Agreement (ACTA) and potentially objectionable content', Declaration of the European Parliament of 9 September 2010 on the lack of a transparent process for the AntiCounterfeiting Trade Agreement (ACTA) and potentially objectionable content, 9-9-9-2010, P7_TA (2010)0317; 'AntiCounterfeiting Trade Agreement', European Parliament resolution of Io March 2010 on the transparency and state of play of the ACTA negotiations, 10-3-2010 P7_TA (2010)0058.

${ }_{23}$ European Commission, Communication from the Commission to the European Parliament, the Council, the European Economic and Social Committee and the Committee of the Regions. A Single Market for Intellectual Property Rights. Boosting creativity and innovation to provide economic growth, and first class products and services in Europe, Brussels, 24 May 20II, $\operatorname{COM(20II)~} 287$ final, I7-19. Enforcement of IP rights within the EU is regulated under Directive 2004/48/EC of the European Parliament and of the Council of 29 April 2004 on the enforcement of intellectual property rights (OJ 195, at 19, 2 June 2004). Implemented in the territory of Member States by April 2006, it lays down remedies for IP rights holders in civil courts. The US government adopted its own strategy on the international enforcement of IP rights in 2013. This was built on the strategy of enforcement adopted by US government in 2010: '2013 Joint Strategic Plan on Intellectual Property Enforcement', U.S. Intellectual Property Enforcement Coordinator, June 20I3, http://www.whitehouse.gov/sites/default/files/omb/IPEC/20I3-us-ipec-joint-strategic-plan.pdf. 
enforcement ${ }^{24}$ would be enough for India and insufficient for the EU. Chapter III of the TRIPS is the longest chapter in the agreement. ${ }^{25}$ It applies to all the intellectual property rights regulated under TRIPS. It requires State parties to provide both civil and administrative remedies in case of infringements of intellectual property rights as well as enforcement measures at the border. ${ }^{26}$ Despite its length, Chapter III does not specify the sanctions and measures to be imposed on infringers.

On the other hand, the FTA cannot be viewed as leading to a real commitment from the parties to harmonize their internal IP laws. Neither India nor the EU has introduced changes in its internal intellectual property laws so as to iron out their specificities since the negotiations started. This shows that neither of the parties is moving towards the elimination of their legal asymmetries in the field of intellectual property. However, as has been pointed above, the TRIPS agreement regime is often ambiguous. More specifically, significant legal differences exist with regard to various topics: the scope of the protected rights, data protection for inventors, the relation between intellectual property and public health, ${ }^{27}$ the granting of second use patents ${ }^{28}$, the definition of the extent of patentability criteria, and the question of exceptions to patentability ${ }^{29}$. Undoubtedly, an effective harmonization on these issues would provide a greater legal certainty to both Indian and European industry. However, it is hard to see how both parties could unify their criteria. As explained, the EU is interested in a more protective intellectual property system, whilst India is satisfied with the existing lack of harmonization and the pre-eminence of the territoriality principle in intellectual property laws. ${ }^{30}$ The latter means that internal intellectual property law takes precedence where the TRIPS agreement is silent or unclear and there are inconsistencies between the EU and the Indian regimes. It is clear that according to Indian interests, any eventual inconsistencies shall not affect internal trade of goods.

24 Chapter III of the TRIPS agreement introduces four sections and twenty articles which specify the type of measures that Member States to the Agreement must respect with regard to the enforcement of intellectual property rights. These provisions are concrete and specific, but not exhaustive.

${ }_{25}$ In effect, this is rather contradictory, as it is not possible to guarantee enforcement of any law without effective sanctions.

${ }^{26}$ From the perspective of innovative industries, the legal scenario in India is unfavourable. These industries require "an effective administrative procedure for obtaining IP rights and a fair and impartial judicial procedure for enforcing them". Intel Comments on India's Draft National IPR Strategy, p. 3, available electronically at <http://dipp.nic.in/English/Discuss_paper/feedBack8_IPRStrategy_orNovember2oI2.pdf>.

27 Supra n. 26.

${ }_{28}$ Whilst the European Patent Office grants second use patents, the Indian Patent Offices refuse them on the basis of the Indian Patent Act (1970) modified in 2005.

29 Under Indian law, patents are not available as regards new forms of an already known substance unless it "differs significantly in efficacy" (art. 3 (d) Patents (Amendment) Act (2005)). On this topic, see: M. Ortega Gómez, Patentes farmacéuticas..., supra n. I, at 208; C. Góñiz López, 'Novartis vs India: patentabilidad y accesibilidad a los medicamentos en el tercer mundo', 267 Revista de Derecho Mercantil (2008) at 197-214; J. H. Reichman, 'Securing Compliance with the TRIPS agreement After US v India', Journal of International Economic Law (1998) at 585-60I.

30 There are important differences between Indian patent law and European law which concern new uses of known substances. Indian law (art. 3 (d) of the Patents Act) does not protect 'any new property or new use for a known substance or of the mere use of a known process, machine or apparatus unless such known process results in a new product or employs at least one new reactant". In Europe, a new therapeutic use of a known product having no previous pharmaceutical use, known as a first indication or "first medical use", is protected by a product patent according to art. 54 of the European Patent Convention. 


\section{TECHNOLOGY TRANSFER}

Technology transfer is of vital importance to developing countries, but it is difficult for developed countries to assume specific commitments in this contex $\mathrm{t}^{3 \mathrm{I}}$ as this would entail a commitment to providing innovation and technology support services at fair prices to the advantage of developing countries. ${ }^{32}$ Instead, technology suppliers have a preference for internal forms of transfer.

Technology transfer has been viewed as a "transfer in" process by which developing countries seek to gain access to technical goods and know-how imported from the developed world. This transfer is generally effected by means of IP licensing agreements (contracts) between universities or private companies, on the one hand, and private companies or publicly owned commercialization agencies, on the other. ${ }^{33}$

There are two broad policy approaches to technology transfer. One is a regulatory approach, which seeks to intervene in the market for technology so as to rectify perceived inequalities in that market as between the technology owner and the technology recipient. ${ }^{34}$ A contrasting approach sees the transfer of technology as best undertaken in a market-based environment. ${ }^{35}$ The "market-based development" approach is characteristic of the TRIPS agreement. ${ }^{36}$ This is the formula preferred by developed countries with advanced technology; these countries avoid (for obvious reasons) assuming

${ }^{31}$ On this topic, see: United Nations Conference on Trade and Development, 'Transfer of Technology', UNCTAD Series on issues in international investment agreements, 200I, http://unctad.org/en/docs/psiteiitd28.en.pdf. The UNCTAD established a code of conduct on Technology Transfer in 1985 entitled 'Draft International Code of Conduct on the Transfer of Technology', 1985. For a general discussion on this topic, see Coonrod, 'The United Nations Code of Conduct for Transnational Corporations', I8 HARV. INT'L L.J. (1977) at 273; K. E. Maskus: 'Encouraging International Transfer of Technology' (UNCTAD-ICTSD, May 2004, http://www.ictsd.org/downloads/2008/o7/b.pdf); M. Montañà Mora, 'El acuerdo ADPIC de la Organización Mundial del Comercio y la transferencia de tecnología, in La Propiedad Intelectual e Industrial: garantía para la economía del conocimiento, (Círculo de empresarios, Madrid, 2009).

32 The World Health Organization (WHO) proposed new formulas in order to assure technology transfer for the benefit of the South. None of them entails the assumption of any sort of legal commitment. It looked at a "global strategy and plan of action on public health, innovation and intellectual property" and stated that "North-South and South-South development cooperation, partnerships and networks need to be supported in order to build and improve transfer of technology related to health innovation": WHO: "Global strategy and plan of action on public health, innovation and intellectual property', 20II, p. II, http://www.who.int/phi/publications/Global_Strategy_Plan_Action.pdf?ua=I.

33 This has been pointed out by Cynthia Cannady: 'Technology Transfer and Development', WIPO Magazine, September 2006, http://www.wipo.int/wipo_magazine/en/2006/05/article_0005.html.

34 "It focuses on the potentially unequal nature of a technology transfer transaction, especially where the recipient is an enterprise in a developing country. The underlying rationale for provisions displaying this approach is to control the potentially adverse economic consequences of such transfers for the weaker party, which include both the licensee in an external transfer and the developing host country in the case of all transfers. Hence the major features of such provisions include the protection of a host country's internal regulations on technology transfer and the outright prohibition of certain terms in technology transfer transactions that are detrimental to development goals": UNCTAD, Transfer of Technology, UNCTAD, Series on issues in international investment agreements, United Nations, New York-Geneva, 200I, 52. The "regulatory" approach is characteristic of instruments concluded by developing countries in the 1960s and 1970s.

35 This approach abandons the willingness to prohibit specific terms in technology transfer transactions that is characteristic of the "regulatory" approach, relying rather on competition rules to control abuses: UNCTAD, 'Transfer of Technology', UNCTAD Series on issues in international investment agreements (United Nations, New York - Geneva, 200I) at 45 .

36 Under the TRIPS agreement, technology transfer is dealt by the following articles: 7, 8, 30, 3I, 40, 66.2 and 67. Although technology transfer is a prior objective under the TRIPS agreement according to art. 7 , the agreement does not impose any obligation on the State parties in this area. 
international obligations concerning technology transfer and consider that technology transfer must be voluntary unless exceptional reasons arise. ${ }^{37}$

In this area, measures that go beyond rhetorical statements would be welcomed by India. An exchange of views and information relating to both parties' international practices and policies in the field of technology transfer would be a minimum compromise. Furthermore, attention to the education and development of human capital (which are conditions sine qua non) to enable technology transfer to India should also be guaranteed.

Another important issue in this specific context refers to the control of licensing and other abuses of intellectual property rights or abuses of information asymmetries in the negotiation of licenses that may affect the international transfer of technology. In the latter case, the parties ought to make specific commitments to prevent practices that are unfair or impede technology transfer. More specifically, the parties ought to take measures to prevent intellectual property rights holders from abusing information asymmetries in the negotiation of licenses. A future FTA between India and the EU cannot be expected to introduce real commitments with regard to technology transfer. In effect, if the EU accepted specific obligations with regard to technology transfer towards India, this would be extraordinary and uneven as there is no such precedent under international law.

Conversely, in the absence of effective means for technology transfer, any provision on technology transfer in a future EU-India FTA would be practically useless, a declaration that is merely rhetorical.

\section{PATENTS AND PUBLIC HEALTH}

The relationship between patents and public health is another issue of the greatest importance for both negotiating parties. In this context, the question of access to essential medicines is a sensitive issue for India due to the fact that India is the world's largest generic medicine exporter and yet, paradoxically, many Indian citizens lack free access to good quality medicines..$^{8}$ In addition, it is in the EU's interest that worldwide access to essential medicines should not undermine the conditions to generate income from high-risk, research-based enterprises. ${ }^{39}$

37 In the TRIPS negotiations, India stated that "prospective technology seekers in developing countries face serious difficulties in their commercial dealings with technology holders in the developed countries. These difficulties are basically of three kinds: those which arise from the imperfections of the market for technology; those attributable to the relative lack of experience and skill of enterprises and institutions in developing countries in concluding adequate legal arrangements for the acquisition of technology; and those government practices, both legislative and administrative, in both developed and developing countries, which influence the implementation of national policies and procedures designed to encourage the flow of technology to, and its acquisition by, developing countries": WTO, General Council, Preparations for the 1999 Ministerial Conference, Proposals on IPR Issues, Communication from India, received on 2 February 1999, WT/GC/W/I47, at 3 .

38 There are a number of factors that negatively affect access to medicines in India. Amongst others, M. Gupta points to inefficient and iniquitous financing mechanisms and high and unaffordable drug prices. M. Gupta, 'Access to Medicines and Health Technologies in India: Opportunities and Challenges', BRICS Forum Health Technology Access among the BRICS countries: Brazil, Russia, India, China and South Africa, 20I3: http://www.ispor.org/meetings/neworleanso5ı//releasedpresentations/FORUM-I-BRICS_Gupta.pdf; D. Taylor, J. Gill, Health and Health Care in India, University College London, Faculty of Pharmacy, http://www.efpia.eu/uploads/UCL_summary.pdf.

39 As D. Taylor and J. Gill note in their report quoted in n. 38 . 
Considering Indian interests and problems as well as EU interests, both parties have strong reasons to fight for new formulas capable of improving the WTO rules on access to medicines.

That said, reference must be made to the Doha Declaration on TRIPS and public health adopted in year 200I to adapt the TRIPS provisions to the public health needs of developing countries in order to respond to the problem of the lack of access to medicines in these countries. The unaffordable prices of essential medicines are known to represent a serious shortcoming of the international patent system, a problem that the TRIPS agreement aggravated by obliging State parties to protect inventions through patents. However, the General Council of the WTO has not been able to resolve the problem. Certainly, the adoption of the Doha Declaration in $200 \mathrm{r}$ was a good, albeit insufficient, step forward. First of all, it is no more than a non-binding interpretative declaration on the TRIPS agreement ${ }^{40}$, and therefore, too limited to tackle the huge problem of lack of access to essential medicines in developing countries. In effect, the Declaration is excessively succinct: it focuses only on compulsory licenses, which then appear to be the sole formula to combat the lack of access to medicines for people who do not have the means to afford pharmaceutical products under patent protection. ${ }^{4 \mathrm{I}}$ In addition, the Doha Declaration mentions parallel imports solely as an alternative to compulsory licenses, without going into the matter more deeply. Nor does the Declaration address technology transfer on behalf of developing countries as a key factor for development.

The question that arises is whether the draft EU-India FTA will provide new and definitive solutions to this unresolved problem, which is concentrated in Africa and is an acute problem in India as well. ${ }^{42}$ Again, a future FTA cannot be expected to introduce substantial changes in this context; a bilateral agreement can hardly be expected to introduce new rules different from those that apply globally in order to solve the global problem of access to affordable medicines.

\section{THE QUESTION OF DATA PROTECTION}

Data protection is an independent intellectual property right that differs from a patent right. It provides the holder with specific rights, namely that the data generated by the holder may not be

${ }^{40}$ In this sense, see: F.M. Abbot, 'Compulsory Licensing for Public Health Needs: TRIPS Agenda at the WTO after the Doha Declaration on Public Health', Occasional Paper num. 9, Quaker UN Office (QUNO), 9. M. Ortega Gómez, Patentes farmacéuticas y paises en desarrollo, quoted in n. I at 93. Professor C. Correa makes an exhaustive analysis of the Declaration in a study entitled: 'Repercusiones de la Declaración de Doha relativa al Acuerdo sobre los ADPIC y la salud pública' (2002, Universidad de Buenos Aires, www.who.int/medicinedocs/pdf/s4904s/s4904s.pd).

${ }_{4 r}$ The Controller of Patents (Mumbai) issued a compulsory license on the anti-cancer drug Nexavar in 2012 (See: http://www.ipindia.nic.in/ipoNew/compulsory_License_I20320I2.pdf). The compulsory license was issued on the basis of art. 84 of the Patent Act (1970), on a patent held by Bayer. It was upheld by the IPAB on 3 March 2013 on the basis of public interest (IPAB judgment: http://www.ipab.tn.nic.in/045-20I3.htm). Bayer holds an Indian patent for the chemotherapy drug sorafenib tosylate, sold under the trade name Nexavar. On 9 March 2012, the Indian Patent Controller issued a compulsory license to Natco Pharma to manufacture an affordable generic version of sorafenib tosylate. Bayer filed an appeal against the compulsory license before the IPAB which was rejected on 3 March 20I3. The price of the generic drug marketed by Natco is approximately 160 USD for a month's dose, dramatically lower than the price of Nexavar (5,098 USD).

${ }_{42}$ On this topic, see: X. Pons Ràfols, Salud pública mundial y Derecho internacional (Marcial Pons, Madrid-BarcelonaBuenos Aires, 20IO); X. Seuba, La protección de la salud ante la regulación internacional de los productos farmacéuticos (Marcial Pons, Madrid-Barcelona-Buenos Aires, 20ro). 
referred to or used by another person or company for a specific period of time. The regulation of data protection has been considered to be of critical importance by some countries ${ }^{43}$ in order to provide the necessary incentives for companies to generate the necessary data for the registration of pharmaceutical products. ${ }^{44}$

Particularly in the European Union, anyone seeking to register innovative drugs must supply information to the competent authority to demonstrate the drug's safety, its quality and efficacy as well as preclinical and clinical data. ${ }^{45}$ This information is viewed as having commercial value and thus the data deserve public protection. In the EU, Directive $65 / 65 / \mathrm{EC}$ provides a period of data protection of either 6 or 10 years depending on the Member State at issue. ${ }^{46}$

Unlike the EU, India has not yet introduced rules setting out a regime on data protection. The view is that data protection provisions would prevent India's drug regulatory agency from allowing referencing or otherwise relying on registration data previously filed by innovative drug companies in order to gain regulatory approval for therapeutically equivalent generic versions. ${ }^{47}$ Thus, under Indian domestic law, India does not accept a provision that would delay the granting of a second authorization of commercialization for years after the first patent has been granted and that would, in addition, require the applicant to submit his own data or, alternatively, data that the owner of the patent has authorized for use. Initially, the EU argued that products failing to meet these requirements should be excluded from the market. In the absence of data protection, the Indian pharmaceutical industry will face no obstacles to the production and distribution of generic versions of new medicines that are under data exclusivity protection in the EU, once the industry proves that their medicines are bioequivalent to the original ones. In summary, Indian industry would not have to repeat preclinical and clinical tests that innovative industries must develop to guarantee both the safety and the efficacy of a pharmaceutical product.

43 In 1984, the US became the first country to enact data exclusivity legislation under the Hatch-Waxman Act. Under this Act, applications for approval of new drugs receive 5 years of data exclusivity. Other countries that introduce periods for data exclusivity are New Zealand ( 5 years), Japan ( 8 years for new drugs), China (6 years) and Australia ( 5 years).

44 J. Gorlin, 'Encouragement of New Clinical Drug Development: The Role of Data Exclusivity', International Federation of Pharmaceutical Manufacturers Associations", 2000, available electronically at <http://www.who.int/intellectualproperty/topics/ip/en/DataExclusivity_20oo.pdf>.

45 Data protection against disclosure is also provided for in US law and Japanese law. Under US law, drug manufacturers receive five years of exclusivity for new chemical entities and three years of exclusivity for new indications. Biologics manufacturers receive I2 years of exclusivity for new biological products. Exclusivity is extended in some circumstances. For example, the FDA provides for an additional six months of exclusivity for drugs studied for use in a paediatric population, and an additional five years of exclusivity for drugs designated as Qualified Infectious Disease Products. Under Japanese law, the abridged procedure for obtaining marketing authorization for generic drugs is not available until the re-examination period for the original drug has expired. This effectively operates as a time barrier before which a generic product cannot be approved for marketing.

46 The larger Member States provide io years, while the smaller ones provide 6 years. According to Regulation 2309/93/EC, products which are approved through the centralized procedure have a Io-year period of data protection. (Council Regulation (EEC) No 2309/93 of 22 July 1993 setting out Community procedures for the authorization and supervision of medicinal products for human and veterinary use and establishing a European Agency for the Evaluation of Medicinal Products (OJEU No L 2I4 of 24.8.1993, p. I).

47 S. Reddy, G. Singh Sandhu, 'Report on Steps to be taken by Government of India in the Context of Data Protection Provisions of Article 39.3 of TRIPS Agreement' (Report, Government of India, 3I May 2007, http://chemicals.nic.in/DPBooklet.pdf). 
When the FTA negotiations between India and the EU began, the question of data protection was one of the most controversial questions. The EU sought India's commitment to guaranteeing data protection against disclosure beyond the wording of article 39.3 TRIPS. Under the TRIPS agreement, article 39.3 provides for data protection against unfair competition. 48 More particularly, this provision49 applies to pharmaceutical products that utilize new chemical entities where the State party to the agreement requires the submission of data during the marketing authorization process.

Article 39.3 lays down two main ideas:First, it imposes the following obligation on the State parties: Data on new chemical entities, the collection of which involved considerable effort, must be protected against unfair commercial use. Second, as far as the scope of this protection is concerned, such data must be protected against disclosure, except where necessary to protect the public.50

It appears extremely unlikely that India will make international commitments with regard to data protection that go beyond art. 39.3 of the TRIPS agreement on undisclosed data protection5I given that, as previously indicated, India has not yet even introduced specific rules to implement article 39.3 into domestic law.

\section{FINAL CONSIDERATIONS}

When the EU-India negotiations began, the opposing positions of India and the EU on the IP chapter of the FTA seemed irreconcilable. After years of negotiations, however, it appears clear that India is imposing its will so that if the FTA is finally concluded it shall not introduce TRIPS-plus

${ }^{48}$ Art. Io bis of the Paris Convention for the Protection of Industrial Property of 20 March 1983 describes unfair competition as "any act of competition contrary to honest practices in industrial or commercial matters".

49 Article 39.3 of the TRIPS agreement reads as follows: "Protection of Pharmaceutical Data Submitted to Obtain a Marketing Authorization. When a Party requires, as a condition of approving the marketing of pharmaceutical products that utilize new chemical entities, the submission of undisclosed test or other data, the origination of which involves a considerable effort, that Party shall protect such data against unfair commercial use. In addition, the Parties shall protect such data against disclosure, except where necessary to protect the public, or unless steps are taken to ensure that the data are protected against unfair commercial use".

so As C. Clift points out, "the United States and the European Union have argued that Article 39(3) requires countries to create a regime of 'data exclusivity', a form of time-limited intellectual property right. In the United States and countries in the European Union, a data exclusivity regime for both medicines and agrochemicals was adopted prior to the TRIPS agreement (for example, in 1984 in the United States and in 1987 in the European Union, for medicines). For a period of five years from marketing approval of an originator product, no other company may seek regulatory approval in the United States of an equivalent product based on data submitted by the originator company without the latter's approval. During the period of exclusivity, regulators cannot use (rely on) the originator's data to approve a generic product, even if the product is demonstrated to be exactly equivalent in chemical composition and in its behaviour within the body". C. Clift, "Data Protection and Data Exclusivity in Pharmaceuticals and Agrochemicals", in Intellectual Property Management in Health and Agricultural Innovation: A Handbook of Best Practices (eds. A Krattiger, RT Mahoney, L Nelsen, et al.). MIHR: Oxford, U.K., and PIPRA: Davis, U.S.A. Available online at www.ipHandbook.org. Satyanarayana K, S Srivastava and NK Ganguly. 'Data Protection Issues in India', at 123:723-726, 2006, medind.nic.in/iby/to6/i6/ibyto6i6p723.pdf. WIPO. 1996. Model Provisions on Protection against Unfair Competition. World Intellectual Property Organization: Geneva www.wipo.int/cfdiplaw/en/trips/doc/unfair_competition.doc.

${ }_{51}$ According to art. 39.3, "members, when requiring, as a condition of approving the marketing of pharmaceutical or of agricultural chemical products which utilize new chemical entities, the submission of undisclosed test or other data, the origination of which involves a considerable effort, shall protect such data against unfair commercial use. In addition, Members shall protect such data against disclosure, except where necessary to protect the public, or unless steps are taken to ensure that the data are protected against unfair commercial use". 
commitments. According to this view, India would be imposing its stance on the role of international law on intellectual property protection in the framework of the FTA negotiations. Indian views are consistent with its status as a developing country and its position as the world's leading producer of low-cost pharmaceuticals for the developing world.

On the other hand, the EU's ultimate acceptance of Indian views would be evidence of EU weakness in the field of international intellectual property law. Such weakness could be interpreted and explained by India's concessions in other contentious chapters of the FTA under negotiation. ${ }^{52}$ Alternatively, it could simply be another sign that the EU does not have effective bargaining power and strength relative to its allies in the context of international relations and that it is a "soft" negotiator, without the necessary power and conviction to impose its will. All in all, this shows that the EU is unable to export its intellectual property rights model in its relations with the most important producer of generic pharmaceuticals in the world.

${ }_{52}$ Supra note 3, p. I34. 